\title{
Phosphodiesterase 5 is main regulator of brown adipocyte differentiation
}

\author{
Ana Kilić, Thorsten Gnad, Linda S Hoffmann, Alexander Pfeifer \\ From 6th International Conference on cGMP: Generators, Effectors and Therapeutic Implications \\ Erfurt, Germany. 28-30 June 2013
}

\section{Background}

Obesity, a major threat to global human health, has been shown to be associated with devastating diseases such as stroke, hypertension, cancer and type 2 diabetes. In order to fight the present obesity pandemic it is crucial to better understand regulation of adipocyte differentiation. Phosphodiesterases (PDEs) catalyze hydrolysis of cyclic nucleotides (cyclic adenosine monophosphate (cAMP) and cyclic guanosine monophosphate (cGMP)) to the corresponding $5^{\prime}$ nucleotide monophosphates. To date, eleven different PDEs (PDE1-11) have been characterized, and they differ in their selectivity for cyclic nucleotides, sensitivity to inhibitors and activators, physiological roles, and tissue distribution. The nonselective phosphodiesterase inhibitor isobutylmethylxanthine (IBMX) has been shown to be essential for successful in vitro differentiation of adipocytes.

\section{Results}

In the present study, we differentiated brown adipocytes in vitro and substituted IBMX with selective PDE-inhibitors; Vinpocetin (PDE1; $10 \mu \mathrm{M})$, EHNA (PDE2; $1 \mu \mathrm{M}$ ), Cilostamide (PDE3; $50 \mathrm{nM}$ ) and Vardenafil (PDE5; $20 \mu \mathrm{M}$ ) during induction period only or during whole differentiation protocol. Moreover, we directly compared the effects of cAMP and cGMP on brown fat cell differentiation. We show that PDEs (PDE1-5) are expressed in preadipocytes. Omission of IBMX prevented brown adipocyte differentiation. Substitution of IBMX with PDE1, PDE2 and PDE3 inhibitors had no effect on lipid accumulation, while addition of PDE5 inhibitor slightly promoted adipogenesis as seen in Oil Red $\mathrm{O}$ staining and expression of adipogenic markers (CCAAT/enhancer-binding protein $\alpha(\mathrm{C} / \mathrm{EBP} \alpha)$ and ap2). In addition, chronic treatment of brown

\footnotetext{
* Correspondence: akilic@uni-bonn.de

* Correspondence: akilic@uni-bonn.de
Institute of Pharmacology and Toxicology, University of Bonn, Sigmund Freud-Str. 25, Germany
}

adipocytes with Vardenafil together with cGMP promoted adipogenesis to the levels reached with IBMX treatment. Interestingly, constant application of $200 \mu \mathrm{M}$ cGMP promoted lipid accumulation as well as the expression of adipogenic markers (C/EBP $\alpha$ and ap2) while chronic treatment with $200 \mu \mathrm{M}$ cAMP during brown fat cell differentiation prevented adipogenesis.

\section{Conclusion}

Our in vitro results suggest that PDE5 is an important player in brown adipocyte differentiation and indicate that inhibition of PDE5 might have therapeutic implication in treating obesity and related disorders such as stroke and Type 2 diabetes.

Published: 29 August 2013

doi:10.1186/2050-6511-14-S1-P32

Cite this article as: Kilić et al:: Phosphodiesterase 5 is main regulator of brown adipocyte differentiation. BMC Pharmacology and Toxicology 2013 14(Suppl 1):P32.

Submit your next manuscript to BioMed Central and take full advantage of:

- Convenient online submission

- Thorough peer review

- No space constraints or color figure charges

- Immediate publication on acceptance

- Inclusion in PubMed, CAS, Scopus and Google Scholar

- Research which is freely available for redistribution

Submit your manuscript at www.biomedcentral.com/submit
() Biomed Central
C Biomed Central

๑ 2013 Kilićć et al; licensee BioMed Central Ltd. This is an Open Access article distributed under the terms of the Creative Commons Attribution License (http://creativecommons.org/licenses/by/2.0), which permits unrestricted use, distribution, and reproduction in any medium, provided the original work is properly cited. 